\title{
EHMTI-0339. Pain 101: managing complex chronic headaches across the lifespan
}

\author{
B Dick ${ }^{1 *}$, M Simmonds ${ }^{1}$, S Rashiq ${ }^{1}$, K Reid $^{2}$, M Verrier $^{1}$ \\ From 4th European Headache and Migraine Trust International Congress: EHMTIC 2014 \\ Copenhagen, Denmark. 18-21 September 2014
}

\section{Introduction}

Headache pain has been found to be a common pain complaint across cultures. Much remains to be learned regarding the etiology and biological treatments of complex headaches. Much is unknown regarding etiology and biological treatments of headache

\section{Aim}

To examine the efficacy of a best practice psychological treatment program based on 3rd wave cognitive- behaviour therapy incorporating Mindfulness-Based Stress Reduction in adolescents and adults with complex headaches.

\section{Method}

Outpatients referred to Stollery Children's Hospital's Pediatric Chronic Pain Clinic and University of Alberta Hospital Multidisciplinary Pain Centre were enrolled in the Pain 101 pain management program. Of these individuals, 52 adolescents and 139 adults reported complex headache. Pain 101 uses 10 psychoeducational group sessions aimed at the key areas of pain education, reducing physiological arousal, goal setting and activity management, cognitive reappraisal and acceptance, and emotional regulation. Data collection is targeted for five years post-assessment.

\section{Results}

Headache sufferers across the lifespan showed significant reductions in pain, pain-related disability, anxiety, painrelated fear, and a significant improvement in sleep and quality of life. Adults but not pediatric patients showed depression reduction. In adults, some of these improvements were durable over time to five years post-treatment. Insufficient data is available in the pediatric

${ }^{1}$ Anesthesiology and Pain Medicine, University of Alberta, Edmonton, Canada Full list of author information is available at the end of the article population at present to reliably discern outcomes past 6-months post-treatment.

\section{Conclusion}

The Pain 101 program shows promise for managing complex headaches and its clinical sequellae. The program successfully reduced disability, improved mood, and increased quality of life in a cost-effective treatment setting. Treatment effects lasted for an extended period post-treatment.

No conflict of interest.

\section{Authors' details}

${ }^{1}$ Anesthesiology and Pain Medicine, University of Alberta, Edmonton, Canada. ${ }^{2}$ Pediatric Chronic Pain Clinic, Stollery Children's Hospital, Edmonton, Canada.

Published: 18 September 2014

doi:10.1186/1129-2377-15-S1-D15

Cite this article as: Dick et al.: EHMTI-0339. Pain 101: managing complex chronic headaches across the lifespan. The Journal of Headache and Pain 2014 15(Suppl 1):D15.

Submit your manuscript to a SpringerOpen ${ }^{\odot}$ journal and benefit from:

- Convenient online submission

- Rigorous peer review

- Immediate publication on acceptance

- Open access: articles freely available online

- High visibility within the field

- Retaining the copyright to your article

Submit your next manuscript at $\boldsymbol{~ s p r i n g e r o p e n . c o m ~}$ (c) 2014 Dick et al; licensee Springer. This is an Open Access article distributed under the terms of the Creative Commons Attribution License (http://creativecommons.org/licenses/by/2.0), which permits unrestricted use, distribution, and reproduction in any medium, provided the original work is properly cited. 